\title{
Optimization and Research on Environmental Effect with Sewage Diffuser in DA Ya Bay
}

\author{
Hang YU \\ Tianjin Research Institute for Water Transport Engineering, Tianjin 300456 \\ yuhang0709@sina.com
}

\begin{abstract}
Keyword: marine diffuser; environmental effect; physical model
Abstract: The sewage diffuser is an environmental material for protecting marine environment. It plays an important role in port engineering. Its effect under deep water was carried out between different diffuser design parameters based on the hydraulic model test, and DA Ya Bay sewage marine disposal project was taken as an example. In DA Ya Bay project, jet angle was controlled to be 0 degree, azimuth angle was controlled to be 0 degree, and the length is 135 meters. It not only can ensure that sewage fully diluted mixed, also can avoid the premature convergence and sewage lifting. It is feasible for selecting large angle nozzle under deep water and there are some technical bases have been provided for other sewage marine disposal project.
\end{abstract}

\section{Introduction}

Sewage diffuser is a new material which is used to marine environmental protection. In this article, the DA Ya Bay sewage marine disposal project was taken as an example, diffuser for sewage dilution has been analyzed in deep water based on the physical model test technique. It ensures the implementation of sewage marine disposal project, and put forward to take dip nozzle diffuser structure. It provides a theoretical basis for the future to carry out deep water sewage deep sea discharge study.

\section{Research statuses}

The diffuser of California Ohno sewage marine disposal project[1] used the single nozzle structure on the rising pipe, the diameter of rising pipe is bigger than the nozzle diameter, it flowed by elbow bend; the project of Australia's North Head[2] used "I" structure diffuser and it is multi nozzle structure, the space of two rising pipe is $21 \mathrm{~m}$, every rising pipe had 6 jets; Malabar sewage marine disposal engineering[2] used "L" structure diffuser and every rising pipe had 8 jets; the hydraulic model tests of the United States of America Boston sewage discharged engineering ${ }^{[1]}$ shows that plume discharge nozzle can form a raised ring when the nozzles of rising pipe are more than eight, it will reduce the extent of dilution of sewage; Wilkinson studied the seawater full time of pipe discharge system, it provided reference to predict water wedge formation and development as well as the cleaning time and cleaning process. YAN Zhong-min[3] studied the dilution characteristics of porous diffuser in finite depth waters and the limited width of near-field which combined with the development direction of river discharge in China; according to the physical model test,XU Gao-tian, WEI He-ping[4] improved the design of diffuser which combined with features of Shang hai city sewage treatment project; WANG Chao[5] put forward "T" structure diffuser from shipping, construction and other point of view; ZHANG Guang-yu, ZHAN Shui-fen[6] comprehensively studied the effects of sewage diffusion in near field about horizontal azimuth, jet angle, length, depth of water, jet velocity and other design parameters.

\section{Research example}

\section{(1) Model design}

Due to the speed difference between the jet and ambient water in the vicinity of the outfall vary greatly, the jet with environmental water blending process has a strong three-dimensional, so it must use the normal physical model. Model designed according to Froude guidelines, the flow pattern in 
the model must be uniform to the prototype. Reynolds number should be greater than the critical Reynolds number for the flow pattern is similar to the model vents.

$$
\mathrm{R}_{\mathrm{e} j \min }=\frac{u_{j \min } D_{\min }}{v} \geq \mathrm{R}_{\mathrm{ec}}
$$

$\mathrm{R}_{\mathrm{e} j \min }$ — the orifice Reynolds minimum in the model; ${ }_{j \min }$ - the minimum orifice flow rate in the model(m/s); $D_{\text {min }}$-The minimum orifice diameter in the model(m); $v$ - the water sports viscous coefficient; $\mathrm{R}_{\mathrm{ec}}$-critical Reynolds number.

\section{(2) Analysis of test results}

Analysis of the results of different azimuth

The vents level azimuth directly related to sewage jet path and diluted diffusion effect on the project, there are three programs which include the azimuth of $0^{\circ}, 45^{\circ}, 90^{\circ}$ as a physical model test program. Table 1-Table 2 are the test results of different azimuth.

Table $1.0^{\circ}$ azimuth test results

\begin{tabular}{|c|c|c|c|c|}
\hline \multirow{2}{*}{ Tide } & \multirow{2}{*}{$\begin{array}{l}\text { Length of } \\
\text { diffuser }\end{array}$} & \multicolumn{3}{|c|}{ Dilute multiple } \\
\hline & & $50 \mathrm{~m}$ & $150 \mathrm{~m}$ & $350 \mathrm{~m}$ \\
\hline \multirow{2}{*}{ High tide } & $90 \mathrm{~m}$ & 163 & 258 & 270 \\
\hline & $135 \mathrm{~m}$ & 147 & 209 & 244 \\
\hline \multirow{2}{*}{ Falling tide } & $90 \mathrm{~m}$ & 158 & 252 & 263 \\
\hline & $135 \mathrm{~m}$ & 143 & 200 & 241 \\
\hline \multirow{2}{*}{$\begin{array}{c}\text { Recreation } \\
\text { stream }\end{array}$} & $90 \mathrm{~m}$ & \multicolumn{3}{|c|}{ Diffusion range: $0.069 \mathrm{~km}^{2}$} \\
\hline & $135 \mathrm{~m}$ & \multicolumn{3}{|c|}{ Diffusion range: $0.075 \mathrm{~km}^{2}$} \\
\hline
\end{tabular}

Table $2.45^{\circ}$ azimuth test results

\begin{tabular}{|c|c|c|c|c|}
\hline \multirow{2}{*}{ Tide } & \multirow{2}{*}{$\begin{array}{l}\text { Length of } \\
\text { diffuser }\end{array}$} & \multicolumn{3}{|c|}{ Dilute multiple } \\
\hline & & $50 \mathrm{~m}$ & $150 \mathrm{~m}$ & $350 \mathrm{~m}$ \\
\hline \multirow{2}{*}{ High tide } & $90 \mathrm{~m}$ & 166 & 240 & 243 \\
\hline & $135 \mathrm{~m}$ & 150 & 172 & 251 \\
\hline \multirow{2}{*}{ Falling tide } & $90 \mathrm{~m}$ & 167 & 234 & 258 \\
\hline & $135 \mathrm{~m}$ & 162 & 235 & 238 \\
\hline \multirow{2}{*}{$\begin{array}{l}\text { Recreation } \\
\text { stream }\end{array}$} & $90 \mathrm{~m}$ & \multicolumn{3}{|c|}{ Diffusion range: $0.071 \mathrm{~km}^{2}$} \\
\hline & $135 \mathrm{~m}$ & \multicolumn{3}{|c|}{ Diffusion range: $0.078 \mathrm{~km}^{2}$} \\
\hline
\end{tabular}

When the azimuth is $0^{\circ}$, the jet perpendicular to the flow direction for the environment, sewage initial dilution is best; the reason is the sewage rapidly mixes with ambient water which is subject to strong perturbations of the environmental flow. Due to the environmental depth of this project is big, it is not easy to be formed the sewage mass on the surface, it is conducive to secondary dilution and diffusion of the sewage, so it has less impact for the environment.

Analysis of the results of different jet angle

The jet angle is one of the important factors that affect the dilution of sewage, it is very important for starting dilution, but it is not has a complete computing model currently. On the project, due to the water depth conditions is better, according to the actual situation it can be 
appropriately increase jet angle, the jet angle of $0^{\circ}, 10^{\circ}, 15^{\circ}$ three programs, as a physical simulation test program to verify. Table 3-Table 4 are the test results of different jet angel.

Table 3. $0{ }^{\circ}$ jet angle test results

\begin{tabular}{|c|c|c|c|c|}
\hline \multirow{2}{*}{ Tide } & \multirow{2}{*}{$\begin{array}{c}\text { Length of } \\
\text { diffuser }\end{array}$} & $50 \mathrm{~m}$ & $150 \mathrm{~m}$ & $350 \mathrm{~m}$ \\
\cline { 2 - 5 } & $90 \mathrm{~m}$ & 161 & 255 & 268 \\
\hline \multirow{3}{*}{ High tide } & $135 \mathrm{~m}$ & 145 & 207 & 242 \\
\cline { 2 - 5 } & $90 \mathrm{~m}$ & 156 & 250 & 261 \\
\hline \multirow{2}{*}{ Falling tide } & $135 \mathrm{~m}$ & 141 & 198 \\
\hline \multirow{2}{*}{$\begin{array}{c}\text { Recreation } \\
\text { stream }\end{array}$} & $90 \mathrm{~m}$ & $135 \mathrm{~m}$ & \multicolumn{3}{|c|}{ Diffusion range: $0.069 \mathrm{~km}^{2}$} \\
\cline { 2 - 5 } & \multicolumn{3}{|c|}{ Diffusion range: $0.075 \mathrm{~km}^{2}$} \\
\hline
\end{tabular}

Table $4.15^{\circ}$ jet angle test results

\begin{tabular}{|c|c|c|c|c|}
\hline \multirow{2}{*}{ Tide } & \multirow{2}{*}{$\begin{array}{c}\text { Length of } \\
\text { diffuser }\end{array}$} & $50 \mathrm{~m}$ & $150 \mathrm{~m}$ & $350 \mathrm{~m}$ \\
\cline { 2 - 5 } & $90 \mathrm{~m}$ & 147 & 242 & 275 \\
\hline \multirow{3}{*}{ High tide } & $135 \mathrm{~m}$ & 130 & 194 & 253 \\
\cline { 2 - 5 } & $90 \mathrm{~m}$ & 143 & 185 & 266 \\
\hline \multirow{2}{*}{ Falling tide } & $135 \mathrm{~m}$ & 128 & \multicolumn{3}{|c|}{ Dilute multiple } \\
\cline { 2 - 5 } Recreation \\
stream
\end{tabular}

The tests showed that longitudinal diffusion related to the shape of jet angle, the greater the angle of jet and perpendicular, after injection of the jet, due to hydraulic around the flow resistance, jet slowly bend, in the meantime, the jet and the cross flow cross mixed slowly, and its width growing. When the jet angle is $0^{\circ}$, due to strong environmental flow disturbance and the sewage has some drift distance, it is difficult to form sewage mass, the project can achieve better dilution and diffusion. Considering the actual water depth in the project, diffuser jet angle is recommended $0^{\circ}$. Analysis of different diffuser length

The length of the diffuser is one of the important factors that affect the dilution and diffusion of sewage. Considering the water quality requirement of sewage discharge field in this project is relatively high, it is selected different programs of diffuser length $(90 \mathrm{~m} \sim 135 \mathrm{~m})$ for physical model tests, and makes sure the diffuser length program.

Table 5. 90m diffuser; $0^{\circ}$ azimuth; jet angle $0^{\circ}$ test results

\begin{tabular}{|c|c|c|c|c|}
\hline \multirow{2}{*}{ Tide } & \multirow{2}{*}{$\begin{array}{c}\text { Length of } \\
\text { diffuser }\end{array}$} & $50 \mathrm{~m}$ & $150 \mathrm{~m}$ & $350 \mathrm{~m}$ \\
\cline { 3 - 5 } & $90 \mathrm{~m}$ & 161 & 228 & 252 \\
\hline High tide & $90 \mathrm{~m}$ & 154 & 225 & 247 \\
\hline Falling tide & $90 \mathrm{~m}$ & \multicolumn{3}{|c|}{ Diffusion range: $0.081 \mathrm{~km}^{2}$} \\
\hline $\begin{array}{c}\text { Recreation } \\
\text { stream }\end{array}$ & \multicolumn{3}{|c|}{} \\
\hline
\end{tabular}


Table 6. $135 \mathrm{~m}$ diffuser; $0^{\circ}$ azimuth; jet angle $0^{\circ}$ test results

\begin{tabular}{|c|c|c|c|c|}
\hline \multirow{2}{*}{ Tide } & \multirow{2}{*}{$\begin{array}{c}\text { Length of } \\
\text { diffuser }\end{array}$} & $50 \mathrm{~m}$ & $150 \mathrm{~m}$ & $350 \mathrm{~m}$ \\
\cline { 3 - 5 } & $135 \mathrm{~m}$ & 144 & 166 & 245 \\
\hline High tide & $135 \mathrm{~m}$ & 141 & 160 & 242 \\
\hline Falling tide & $135 \mathrm{~m}$ & \multicolumn{3}{|c|}{ Diffusion range: $0.049 \mathrm{~km}^{2}$} \\
\hline $\begin{array}{c}\text { Recreation } \\
\text { stream }\end{array}$ & \multicolumn{3}{|c|}{} \\
\hline
\end{tabular}

The tests showed that two diffusion length can meet the requirements of the initial dilution, however, when the length of $90 \mathrm{~m}$, dilution and dispersion becomes more apparent, and sewage mixed fully in roof, indicating the number of the rising pipeline meets the design requirements. Therefore, the 135m length diffuser can meet the requirements of the design of the initial dilution.

\section{Conclusions}

According to the comprehensive analysis of the physical model tests, it is obtained diffuser length is $135 \mathrm{~m}$ through research and analysis of the physical model tests. It is recommended that the horizontal azimuth is $0^{\circ}$ and the jet angle is $0^{\circ}$. In this way it is not also ensure the sewage and the water fully mixed, meet the dilution requirements, and also be able to avoid formed sewage mass in the sea surface. It can be seen that in the deep water conditions, increases the diffuser jet angle and horizontal azimuth angle can ensure better sewage dilution and diffusion through the DA Ya Bay sewage diffuser physical model test, it can ensure the good operation of the sewage deep discharge project. The sewage diffuser is a key environmental material for port engineering and marine environmental protection.

\section{References}

[1] XIA Qing. Sewage marine disposal design theory and method[M].1996,5.

[2] CHEN Fu, ZHANG Yong-liang, MENG Wei. Experience of urban sewage marine disposal in Australian[J]. Research of environmental Sciences. 1994,7(5): 49-52.

[3] WANG Chao, YAN Zhong-min. Experimental study on the dilution characteristics of the near zone blending emission about river diffuser[J]. Hydraulic journal.1993,6.

[4] XU Gao-tian, WEI He-ping. Dilution at the near field of multi-port discharging wastewater at Bailonggang outfall-Shanghai wastewater treatment project II [J]. Marine environmental Science. 2000,19(4): 41-45.

[5] WANG Chao. Study on flow phenomenon of Tee multiport diffuser discharge[J]. Advances in water sciences. 1995,6(3): 176-181.

[6] ZHANG Guang-yu, ZHAN Shui-fen, YUAN Jun-ling. Model Test on Dilution and Diffusion in the Area Near Diffuser[J]. Traffic Environmental Protection. 2005,26(1): 1-6. 